\title{
Agrobacterium tumefaciens Transformation and Cotransformation Frequencies of Arabidopsis thaliana Root Explants and Tobacco Protoplasts
}

\author{
Sylvie De Buck, Anni Jacobs, Marc Van Montagu, and Ann Depicker \\ Laboratorium voor Genetica, Department of Genetics, Flanders Interuniversity Institute for Biotechnology, \\ Universiteit Gent, K.L. Ledeganckstraat 35, B-9000 Gent, Belgium \\ Accepted 16 February 1998.
}

\begin{abstract}
In view of the recent finding that different T-DNAs tend to ligate and integrate as repeats at single chromosomal positions, the frequency of transformation and cotransformation was determined during cocultivation of Arabidopsis thaliana root explants and Nicotiana tabacum protoplasts with two Agrobacterium strains. The transformation frequency of unselected $A$. thaliana shoots was lower than $1 \%$ whereas that of cocultivated tobacco protoplasts was approximately $18 \%$. The cotransformation frequencies, defined as the frequencies with which cells transformed with a first T-DNA contained a second unselected T-DNA, were approximately $40 \%$ reproducible, irrespective of the selection, the transformation frequency, and the plant system used. Extrapolation of these results suggests that at least two independently transferred T-DNAs were present in $64 \%$ of the transformed plant cells. Molecular analysis of cocultivated $N$. tabacum shoots regenerated on nonselective medium showed that only a few transformants had a silenced (2/46) or truncated (1/46) T-DNA. Therefore, most integrated T-DNAs expressed their selectable or screenable markers in primary transgenic plants. Remarkably, 10 to $30 \%$ of the selected $A$. thaliana shoots or progenies lost the T-DNA marker they were selected on. As these regenerants contained the unselected T-DNA with a high frequency $(17 \%)$, these selected plants might result from the expression of unstable, transiently expressed T-DNAs. In conclusion, a significant part of the T-DNAs is lost from the transformed cells.
\end{abstract}

Additional keywords: gene silencing, T-DNA transfer, transgene expression.

Cotransformation of one plant cell by different T-DNAs from different agrobacteria has been demonstrated in several studies (Depicker et al. 1985; Petit et al. 1986; De Block and Debrouwer 1991; Komari et al. 1996; De Neve et al. 1997). Recently, it has been shown that cotransformed T-DNAs integrate as inverted copies, oriented in an inverted or tandem configuration in more than $70 \%$ of the transformants (De Neve et al. 1997). This observation is of particu-

Corresponding author: A. Depicker, Laboratorium voor Genetica, Universiteit Gent, K.L. Ledeganckstraat 35, B-9000 Gent, Belgium. Fax: 32-9-2645349; E-mail anpic@gengenp.rug.ac.be lar importance in view of the correlation between transgene repeats and transgene silencing. Genes or transgenes that are present in multiple copies as clustered units seem to have an enhanced susceptibility for both transcriptional and posttranscriptional silencing (Meyer and Saedler 1996; Depicker and Van Montagu 1997, and references therein; Stam et al. 1997, and references therein). Frequent cotransformations, as a result of applying optimal transformation conditions, may thus be an important underlying reason for silencing and variation of transgene expression in transgenic plants. We were interested in determining the influence of selection on transformation and cotransformation frequencies during standard Agrobacterium-plant cocultivation conditions. As bacteria are in ample excess relative to the number of plant cells, one would expect that most cocultivated plant cells should be transformed and cotransformed, but this is not the case. Based on the variegated expression pattern after transient expression via cocultivation (Janssen and Gardner 1989; Nam et al. 1997) or infiltration (Kapila et al. 1997), it is clear that not all bacteria are virulent and that not all plant cells are accessible or competent. There are several barriers and a successful Agrobacterium-plant cell interaction is dependent on many mutual interacting criteria, some of which are considered below.

Actively growing and metabolically active bacteria should be able to migrate through the apoplastic compartment. Toxicity factors may interfere with the propagation of the bacteria (Sahi et al. 1990; Schläppi and Hohn 1992; Escudero et al. 1996), whereas the status of the plant cell surface (Binns 1991), particular species genotypes (Nam et al. 1997), or explant types (Geier and Sangwan 1996, and references therein) may not contain attachment sites for the bacteria. Then, an efficient and prolonged activation of the virulence genes is required to ensure T-strand production and subsequent $\mathrm{T}$-strand transfer to the plant cell (for a review, see Zupan and Zambryski 1995; Sheng and Citovsky 1996; Tinland 1996). Subsequently, the transferred DNA needs to be efficiently transported to the plant cell nucleus and become double stranded in order to allow transient expression.

To obtain transgenic plants, the cells that express extrachromosomal T-DNA copies transiently must be competent for DNA integration and they should be capable of regenerating during the cocultivation and tissue culture conditions 
(Dillen et al. 1996; Tinland 1996). A deficiency of plant enzymes to integrate the T-DNA can seriously hamper transformation frequencies. Indeed, several DNA repair-deficient Arabidopsis thaliana mutants were found that could transiently express transferred DNA but could no longer integrate the T-DNA (Sonti et al. 1995; Nam et al. 1997).

Depicker et al. (1985) investigated whether the efficiency of transformation of tobacco protoplasts after Agrobacterium tumefaciens cocultivation was determined by the plant cell only, or by the infecting bacteria as well. These authors found that a large proportion of protoplasts were competent for stable transformation and that only a minor fraction of the attached bacteria became engaged in effective transformation of the plant cells. On the other hand, De Block and Debrouwer (1991) studied cotransformation of Brassica napus hypocotyl explants by two Agrobacterium strains. After selection for the presence of the first T-DNA marker, the plants were screened for the presence of the second T-DNA marker. The cotransformation frequency for both T-DNAs varied between 39 and $85 \%$. As cotransformation occurred frequently whereas transformation with a single type of bacterium was relatively limited, it was suggested that only some cells in the tissue explant were competent for transformation.

Here, we report on transformation and cotransformation frequencies. The results allow us to confirm that indeed only a limited number of regenerant plant cells in tissue explants are accessible and/or competent for transformation, whereas a high proportion of protoplasts are competent for transformation. During these experiments, we demonstrate that selection for transformed shoots is essential as the fraction of stably transformed regenerating cells is very small. Furthermore, our results show that, in tobacco, selection does not bias the T-DNA integration and stabilization frequencies. Cotransformation frequencies do not change whether or not the first T-DNA has been selected for. As only a few tobacco transformants contained a silenced or truncated T-DNA among the cocultivated shoots that did not express a T-DNA marker, we can conclude that almost all the integrated T-DNAs are expressed. Finally, we provide evidence that T-DNA constructs may often be lost shortly after regeneration of the transformed cells. Transiently expressed, unstable T-DNAs may allow selection of shoots that later on will not contain the T-DNA anymore.

A
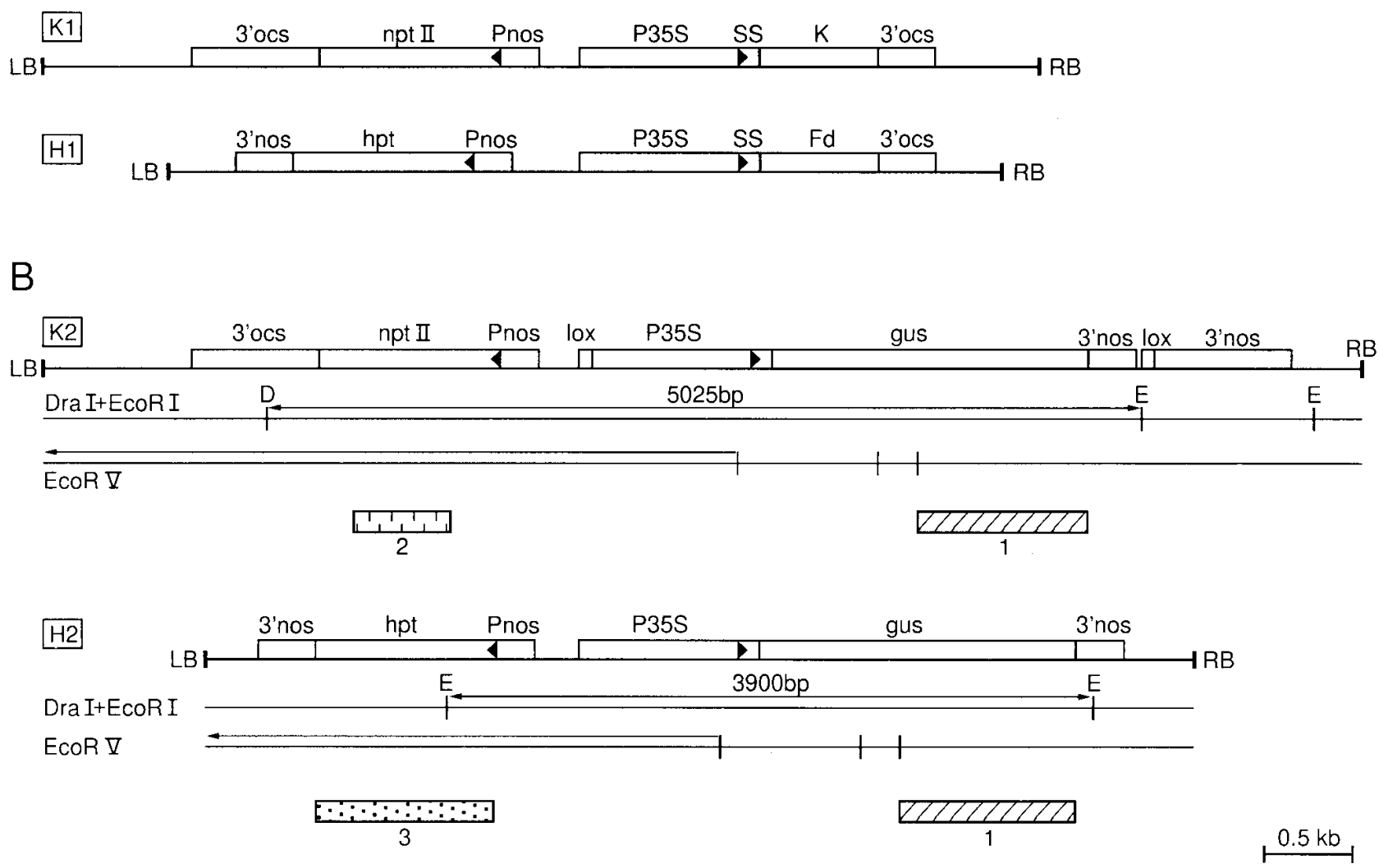

Fig. 1. Schematic outline of $K$ and $H$ types of T-DNA. K T-DNAs in pAK1202 (K $\mathrm{K}_{1}$ T-DNA) and in pK2L610 (K 2 T-DNA) and H T-DNAs in pAG1201 $\left(\mathrm{H}_{1}\right.$ T-DNA) and in pH610 ( $\mathrm{H}_{2}$ T-DNA) are presented. Indicated restriction enzymes DraI, EcoRI, and EcoRV were used for genomic analysis of integrated T-DNAs. Probes are indicated as boxes below sequence: probe 1 hybridizes with $\mathrm{K}_{2}$ and $\mathrm{H}_{2} \mathrm{~T}$-DNAs, whereas probes 2 and 3 are specific for $\mathrm{K}_{2}$ and $\mathrm{H}_{2}$ T-DNAs, respectively. A DraI+EcoRI digest of the $\mathrm{K}_{2}$ T-DNA generates an internal fragment of 5,025 bp from the $\mathrm{K}_{2}$ T-DNA and of 3,900 bp from the $\mathrm{H}_{2}$ T-DNA. These two fragments can be visualized with a gus probe (probe 1). An EcoRV digest in combination with the $n p t I I$ (probe 2) and/or hpt probe (probe 3) reveals left border fragments. Abbreviations: P35S, cauliflower mosaic virus promoter; Pnos, nopaline synthase gene; nptII, neomycin phosphotransferase II gene; hpt, hygromycin phosphotransferase gene; gus, $\beta$-glucuronidase gene; ss, K, Fd, coding sequence for a signal peptide and the mature light chain or Fd fragment of the MAK 33 antibody, respectively (De Neve et al. 1993); 3'ocs, 3' end of the octopine synthase gene; 3'nos, 3' end of the nopaline synthase gene; lox, recognition site of cre/lox recombination system; LB, left border; RB, right border; D, DraI; E, EcoRI. 


\section{RESULTS}

Cotransformation of $A$. thaliana root cells

with two T-DNAs contained by different agrobacteria.

To determine the competence of A. thaliana root cells for transformation, the following experimental strategy was set up. A. thaliana root cells were cocultivated with a mixture of two Agrobacterium strains, each carrying a different T-DNA. One T-DNA contained the kanamycin resistance gene (called the K T-DNA) and the other the hygromycin resistance gene (called the H T-DNA) (see Materials and Methods; Fig. 1). After cocultivation, root explants were grown either on nonselective medium, on kanamycin-containing medium, or on hygromycin-containing medium.

Plants regenerated on nonselective medium were screened on medium with kanamycin or hygromycin to obtain the frequency of transformation and/or cotransformation. Plants obtained after kanamycin or hygromycin selection were analyzed to ensure that they still contained and expressed the T-DNA. Furthermore, they were screened for the not-selected marker to obtain the frequency of cotransformation. The results of the four independent cocultivation experiments on root explants are shown in Table 1 (experiments RE1 to RE4).

In the cocultivation experiments RE1 and RE4, we obtained 51 and 97 shoots, respectively, derived from calli selected on medium with kanamycin (Table 1). By performing a callus induction test (see Materials and Methods), we found that 21 to $35 \%$ of the kanamycin resistance plants were cotransformed with the H T-DNA. Eighteen shoots were found to no longer express the marker they were selected on and to be kanamycin sensitive. However, three of these 18 shoots expressed the nonselected H T-DNA (Table 1; RE4).

In experiments RE2, RE3, and RE4, shoots were obtained derived from calli selected on medium with hygromycin (Table 1). Screening of the $\mathrm{Hyg}^{\mathrm{r}}$ shoots revealed that 30 to $47 \%$ of them also contained the nonselected K T-DNA. Sixteen shoots did not express the hygromycin resistance marker they were selected on. However, four out of these $16 \mathrm{Hyg}^{\mathrm{s}}$ shoots were expressing the nonselected K T-DNA (Table 1; RE4).

On nonselective medium (Table 1), we obtained 116 (RE3) and 56 (RE4) regenerant shoots. None of the shoots expressed either of the selection markers, which means that the transformation frequency of regenerating A. thaliana root cells was lower than $1 \%$.

From these four cocultivation experiments (RE1 to RE4), we can conclude that (i) none of the regenerant shoots derived from nonselective medium are transformed with the $\mathrm{K}$ or $\mathrm{H}$ T-DNAs, (ii) shoots obtained after kanamycin or hygromycin selection are cotransformed with relatively high frequencies (21 to 47\%) with the T-DNA not selected for, and (iii) a significant number of shoots were found to no longer express the marker they were selected for.

\section{Molecular characterization of selected shoots that do not express the T-DNA anymore.}

After kanamycin selection, as well as after hygromycin selection, A. thaliana regenerants were obtained that had become sensitive for the antibiotic they were selected for. These regenerants are generally thought to be escapes from the selection. It is hypothesized that mosaicism in the transformed selected callus allows the outgrowth of nontransformed shoots. Alternatively, the antibiotic-sensitive phenotype in these regenerants may be the result of the silencing of the selective genes. Further, the T-DNA may be unstable and lost during regeneration and differentiation. To distinguish between these possibilities, a molecular screening was performed with the T-DNA located $\beta$-glucuronidase ( $g u s$ ) gene as probe against genomic DNA from one plant selected on kanamycin, but found to be $\mathrm{Kan}^{\mathrm{s}} \mathrm{Hyg}^{\mathrm{r}}$ (RE4) (Table 1), and from six plants selected on hygromycin, but found to be $\mathrm{Hyg}^{\mathrm{s}} \mathrm{Kan}^{\mathrm{s}}$ (RE4) (Table 1). None of these seven regenerants contained a silenced or truncated T-DNA (data not shown). In another cotransformation experiment, upon regeneration 14 shoots on a total of 26 A. thaliana transformants were obtained that did not express the T-DNA marker. Also in this case, none of the selected shoots contained a silenced or truncated T-DNA (data not shown). Finally, in another experiment, we selected six transformants in which the T-DNA proved to be absent, but in which its transient presence could be demonstrated on the basis of reporter enzyme activity (data not shown). Therefore, we conclude that T-DNAs can transiently express the selectable marker, allowing the early selection of A. thaliana

Table 1. Results of the cotransformation experiments on Arabidopsis thaliana root cells

\begin{tabular}{|c|c|c|c|c|c|}
\hline \multirow[b]{2}{*}{ Selection } & \multirow[b]{2}{*}{ Regenerants } & \multicolumn{4}{|c|}{ Experiment } \\
\hline & & $\operatorname{RE1}\left(\mathrm{K}_{1}+\mathrm{H}_{1}\right)$ & $\operatorname{RE2}\left(K_{1}+H_{1}\right)$ & $\operatorname{RE3}\left(K_{2}+H_{2}\right)$ & RE4 $\left(\mathrm{K}_{2}+\mathrm{H}_{2}\right)$ \\
\hline \multirow[t]{5}{*}{ Kanamycin } & Plants isolated & 51 & $\mathrm{NT}^{\mathrm{a}}$ & NT & 97 \\
\hline & $\mathrm{Kan}^{\mathrm{s}}$ plants & $9^{\mathrm{b}} / 51(18 \%)$ & NT & NT & $18^{\mathrm{c}} / 97(18 \%)$ \\
\hline & $\mathrm{Kan}^{\mathrm{s}}$ plants (co)transformed with the $\mathrm{Hyg}^{\mathrm{r}} \mathrm{T}$-DNA & NT & NT & NT & $3 / 18(15 \%)$ \\
\hline & $\operatorname{Kan}^{\mathrm{r}}$ plants & 42 & NT & NT & 79 \\
\hline & $\operatorname{Kan}^{\mathrm{r}}$ plants cotransformed with the $\mathrm{Hyg}^{\mathrm{r}} \mathrm{T}$-DNA & $9 / 42(21 \%)$ & NT & NT & $28 / 79(35 \%)$ \\
\hline \multirow{5}{*}{ Hygromycin } & Plants isolated & NT & 105 & 61 & 57 \\
\hline & Hyg plants & NT & $9^{\mathrm{b}} / 105(8 \%)$ & $7^{\mathrm{c}} / 61(10 \%)$ & $16^{c} / 57(28 \%)$ \\
\hline & Hyg $^{\mathrm{s}}$ plants (co)transformed with the $\operatorname{Kan}^{\mathrm{r}} \mathrm{T}$-DNA & NT & NT & $0 / 7(0 \%)$ & $4 / 16(25 \%)$ \\
\hline & Hyg $^{\mathrm{r}}$ plants & NT & 96 & 54 & 41 \\
\hline & Hyg $^{\mathrm{r}}$ plants cotransformed with the $\operatorname{Kan}^{\mathrm{r}} \mathrm{T}$-DNA & NT & $45 / 96(47 \%)$ & $16 / 54(30 \%)$ & $14 / 41(34 \%)$ \\
\hline \multirow[t]{4}{*}{ Nonselective } & Plants isolated & NT & NT & 116 & 56 \\
\hline & Plants transformed with the $\operatorname{Kan}^{\mathrm{r}} \mathrm{T}$-DNA & NT & NT & $0^{\mathrm{c}}(\leq 1 \%)$ & $0^{c}(\leq 2 \%)$ \\
\hline & Plants transformed with the $\mathrm{Hyg}^{\mathrm{r}}$ T-DNA & NT & NT & $0^{\mathrm{c}}(\leq 1 \%)$ & $0^{\mathrm{c}}(\leq 2 \%)$ \\
\hline & Plants cotransformed with the $\mathrm{Kan}^{\mathrm{r}}$ and $\mathrm{Hyg}^{\mathrm{r}}$ T-DNA & NT & NT & $0(\leq 1 \%)$ & $0(\leq 2 \%)$ \\
\hline
\end{tabular}


calli and shoots, but that the T-DNAs can be unstable in particular cell types and be lost upon regeneration.

\section{Cotransformation of Nicotiana tabacum protoplasts with two T-DNAs contained by different agrobacteria.}

The results described above were obtained with $A$. thaliana root explants and indicated that only a limited number of plant cells were competent for transformation. These competent cells are frequently cotransformed by different bacteria. However, other data suggested that nearly all tobacco protoplasts were competent for transformation and that the limiting step was the formation of a successful Agrobacterium-plant interaction (Depicker et al. 1985). To confirm or correct this conclusion and to evaluate whether selective conditions modify the transformation and cotransformation frequencies, these were determined under selective versus nonselective conditions.

N. tabacum protoplasts were cocultivated (Materials and Methods) with equal amounts of two Agrobacterium strains containing either the $\mathrm{K}_{2}$ T-DNA or the $\mathrm{H}_{2}$ T-DNA (Fig. 1). The regenerating cells were then distributed over nonselective medium, medium with kanamycin, and medium with hygromycin. The results are summarized in Table 2.

From the 98 plants obtained from calli selected on kanamycin-containing medium, one shoot had become Kan ${ }^{\mathrm{s}}$. However, this plant expressed the $\mathrm{Hyg}^{\mathrm{r}}$ marker. The other 97 transformants remained $\mathrm{Kan}^{\mathrm{r}}$ and 40 of those (41\%) also expressed the $\mathrm{Hyg}^{\mathrm{r}}$ marker.

From calli selected on medium with hygromycin, 108 plants were regenerated. One of these plants had become sensitive to the selective antibiotic but did express the resistance marker of the other T-DNA. From the $107 \mathrm{Hyg}^{\mathrm{r}}$ plants, 31 (29\%) were cotransformed with the K T-DNA.

From calli that were grown on nonselective medium, 140 regenerants were obtained, of which 16 expressed the $\operatorname{Kan}^{\mathrm{r}}$ marker (11\%) and 17 the Hyg $^{\mathrm{r}}$ marker (12\%). From the 16 $\mathrm{Kan}^{\mathrm{r}}$ plants, seven were also $\mathrm{Hyg}^{\mathrm{r}}$ (44\% cotransformation). Conversely, from the $17 \mathrm{Hyg}^{\mathrm{r}}$ plants, seven (41\%) were also $\mathrm{Kan}^{\mathrm{r}}$. Of the 140 regenerated tobacco plants, 26 expressed either the $\mathrm{K}$ or the $\mathrm{H}$ T-DNA-linked markers, which corresponded to a total transformation frequency of $18 \%$, whereas

Table 2. Results of the cotransformation experiments on Nicotiana tabacum protoplasts

\begin{tabular}{|c|c|c|}
\hline Selection & Regenerants & Plants (no.) \\
\hline \multirow[t]{5}{*}{ Kanamycin } & Total isolated & 98 \\
\hline & $\mathrm{Kan}^{\mathrm{s}}$ & $1 / 98(1 \%)$ \\
\hline & $\mathrm{Kan}^{\mathrm{s}}$ (co)transformed with $\mathrm{Hyg}^{\mathrm{r}} \mathrm{T}-\mathrm{DNA}$ & $1 / 1$ \\
\hline & $\operatorname{Kan}^{\mathrm{r}}$ & 97 \\
\hline & $\mathrm{Kan}^{\mathrm{r}}$ cotransformed with $\mathrm{Hyg}^{\mathrm{r}} \mathrm{T}-\mathrm{DNA}$ & $40 / 97(41 \%)$ \\
\hline \multirow[t]{5}{*}{ Hygromycin } & Total isolated & 108 \\
\hline & $\mathrm{Hyg}^{\mathrm{s}}$ & $1 / 108(1 \%)$ \\
\hline & Hyg $^{\mathrm{s}}$ (co)transformed with $\mathrm{Kan}^{\mathrm{r}} \mathrm{T}$-DNA & $1 / 1$ \\
\hline & $\mathrm{Hyg}^{\mathrm{r}}$ & 107 \\
\hline & $\mathrm{Hyg}^{\mathrm{r}}$ cotransformed with $\mathrm{Kan}^{\mathrm{r}} \mathrm{T}-\mathrm{DNA}$ & $31 / 97(29 \%)$ \\
\hline \multirow[t]{7}{*}{ Nonselective } & Total isolated & 140 \\
\hline & $\operatorname{Kan}^{\mathrm{r}}$ or $\mathrm{Hyg}^{\mathrm{r}}$ & $26 / 140(18 \%)$ \\
\hline & $\mathrm{Kan}^{\mathrm{r}}$ & $16 / 140(11 \%)$ \\
\hline & $\mathrm{Kan}^{\mathrm{r}}$ cotransformed with $\mathrm{Hyg}^{\mathrm{r}} \mathrm{T}-\mathrm{DNA}$ & $7 / 16(44 \%)$ \\
\hline & $\mathrm{Hyg}^{\mathrm{r}}$ & $17 / 140(12 \%)$ \\
\hline & Hyg $^{\mathrm{r}}$ cotransformed with $\mathrm{Kan}^{\mathrm{r}} \mathrm{T}$-DNA & $7 / 17(41 \%)$ \\
\hline & $\begin{array}{l}\text { Cotransformed with } \operatorname{Kan}^{\mathrm{r}} \text { and } \mathrm{Hyg}^{\mathrm{r}} \\
\text { T-DNA }\end{array}$ & $7 / 140(5 \%)$ \\
\hline
\end{tabular}

seven $(5 \%)$ of the 140 regenerated plants were cotransformed with both T-DNAs. The cotransformation frequencies (44 and $41 \%$ for the $\mathrm{K}$ and $\mathrm{H}$ T-DNA, respectively) were approximately threefold to fourfold higher than the transformation frequency (11 and 12\%, respectively) and are in the same range as those in plants that were selected for the presence of the first T-DNA. This allows us to conclude that the selection regimes do not modify the transformation and cotransformation frequencies.

\section{Molecular screening for the presence of the T-DNA in tobacco plants.}

To determine whether the number of phenotypically transformed tobacco plants represents the actual number of plants containing an integrated T-DNA copy, plants were also characterized at the molecular level. Seventeen plants without resistance markers and 29 plants expressing one, but not the other, resistance marker were analyzed. Screening was initially based on amplification of T-DNA-specific sequences by polymerase chain reaction. However, too many false positive signals in control plants made us change the detection strategy. The presence of either or both T-DNAs was assessed by screening for an internal T-DNA fragment after hybridization with T-DNAspecific probes (Fig. 1). An example is shown in Figure 2.

Of the 17 phenotypically nontransformed plants, one contained a silenced K T-DNA, whereas the 16 other plants had no silenced or truncated T-DNA. Of the 29 plants that expressed only one resistance marker, two were found to also have the second T-DNA. One plant obtained from nonselective medium and expressing the $\mathrm{H}$ T-DNA contained a silenced K T-DNA. In the other plant, a $\mathrm{Kan}^{\mathrm{s}} \mathrm{Hyg}^{\mathrm{r}}$ plant originally selected on medium with kanamycin, a truncated $\mathrm{K}$ T-DNA was found. We conclude from these results that after regeneration only a few tobacco plants may contain a silenced

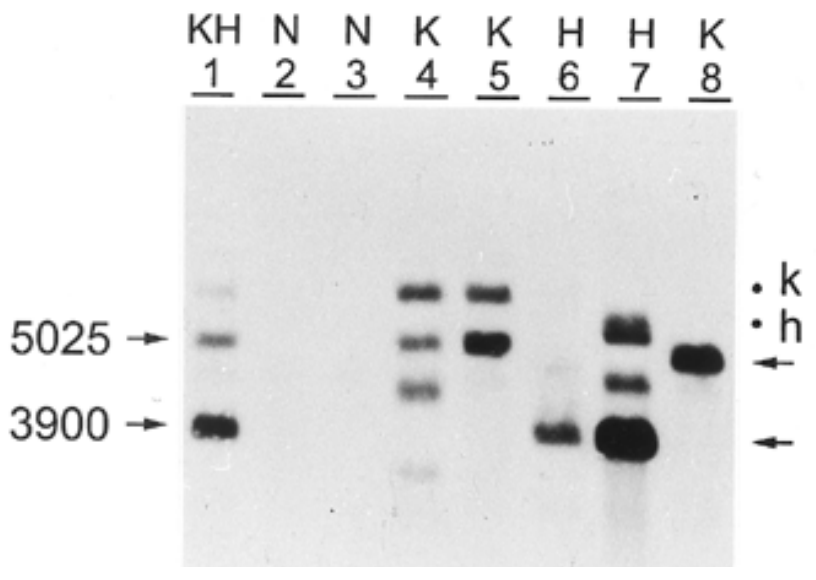

Fig. 2. Southern analysis of tobacco plants to screen for the presence of the K or H T-DNA. A DraI+EcoRI digest in combination with the gus probe (probe 1; see Figure 1) was performed to visualize the presence of the $\mathrm{K}_{2}$ and/or $\mathrm{H}_{2}$ T-DNA. The presence of the K T-DNA is revealed by an internal fragment of 5,025 bp from the $\mathrm{K}_{2}$ T-DNA and by an internal fragment of 3,900 bp from the $\mathrm{H}_{2}$ T-DNA. The plant in lane 1 contains both $\mathrm{K}_{2}$ and $\mathrm{H}_{2}$ T-DNA $(\mathrm{KH})$. In lanes 4,5 , and 8 , the plants contain only the $\mathrm{K}_{2}$ T-DNA (K), whereas plants with only the $\mathrm{H}_{2}$ T-DNA are shown in lanes 6 and $7(\mathrm{H})$. No T-DNA is integrated into the plants of lanes 2 and 3 . $\bullet \mathrm{k}$, and $\bullet \mathrm{h}$ indicate fragments obtained after partial digestions of the K T-DNA and the H T-DNA (confirmed by the EcoRI digest), respectively. 
or truncated T-DNA and, thus, that most transferred and stabilized T-DNAs are expressed in primary transgenic shoots.

\section{DISCUSSION}

Here, we analyzed the susceptibility of A. thaliana root cells and $N$. tabacum protoplasts for transformation and cotransformation by a mixture of two Agrobacterium strains. None of the 172 plants regenerated on nonselective medium from cocultivated $A$. thaliana roots were transformed with either the $\mathrm{K}$ and/or H T-DNA. This observation shows that less than $1 \%$ of the root cells that regenerate into shoots are accessible for the bacteria and/or competent for stable transformation. The transformation frequency of cocultivated tobacco protoplasts that regenerate into shoots is dramatically different: $18 \%$ of the plants are transformed with the $\mathrm{K}$ and/or the $\mathrm{H}$ T-DNA. This result confirms that a large fraction of protoplasts of $N$. tabacum are competent for transformation, as was found by Depicker et al. (1985). However, contrary to what was stated there, not all cells were found to be competent.

The difference in competence of the A. thaliana root cells and the $N$. tabacum protoplasts for stable transformation can be based on several factors, none of which are mutually exclusive. First of all, we used two different plant species, A. thaliana and N. tabacum. It is well known that T-DNA transfer is genotype dependent. Furthermore, the cocultivated tissues are very different; the $A$. thaliana root cells are part of a structured tissue whereas the tobacco protoplasts are individual cells. As the cells that become transformed in the root explants are found among the pericycle cells (Sangwan et al. 1992; M. Van Lijsebettens, personal communication) and never among the epidermal and vascular bundle cells, it is plausible to assume that accessibility and cell differentiation may be important parameters for stable transformation to occur. Also, the physiology of the cells may determine the competence for stable transformation. The root pericycle cells give rise to stably transformed calli only after auxin pretreatment (Sangwan et al. 1992). Tobacco protoplasts are more efficiently transformed during the $\mathrm{S}$ and $\mathrm{M}$ phases than during the other phases of the cell cycle (Meyer et al. 1985; Bower and Birch 1990). Also, after wounding, a defined time period is found during which the cells are more susceptible to A. tumefaciens transformation ("window of competence"; for a review, see Binns and Thomashow 1988). The competent physiology of plant cells for stable transformation may therefore also be strongly correlated with the competence for T-DNA stabilization. Benediktsson et al. (1995) found that irradiation of cells with sublethal doses of X-rays or UV light and certain DNA-damaging drugs increase the transformation frequency and they hypothesized that the increased transformation rate is based on the induction of a particular metabolic activity in the cells. For instance, DNA damage might induce repair mechanisms that may be essential for integration of foreign DNA. Consistent with this hypothesis is the isolation of A. thaliana mutants in which a defective repair mechanism correlates with a deficiency for stable transformation (Sonti et al. 1995). Also, particular ecotypes of $A$. thaliana would be recalcitrant for DNA integration (Nam et al. 1997). Furthermore, the presence of transient mRNA in maize suggests that in this monocotyledonous species T-DNA integration is defective (Narasimhulu et al. 1996).
Until now, the transformation frequencies have always been determined on the basis of phenotypic expression of the introduced genes. It is, however, interesting to know whether this selection would not result in the recovery of only a subpopulation of transformed cells. Several reports suggest that T-DNAs may become silenced soon after transformation (Peach and Velten 1991; Matzke and Matzke 1995; Meyer and Saedler 1996). If this were the case, the transformation as well as cotransformation frequencies found in our study would be much higher than the frequencies observed. Therefore, genomic blot analyses were performed on 21 A. thaliana and $46 \mathrm{~N}$. tabacum shoots. None of the $21 \mathrm{~A}$. thaliana shoots showed the presence of a silenced or truncated T-DNA. Of the 46 screened $N$. tabacum transformants, two plants contained a silenced T-DNA and one plant a truncated T-DNA. Therefore, we can conclude that both for A. thaliana and N. tabacum only a few plants may contain a silenced T-DNA after regeneration and, thus, that most transferred and stabilized T-DNAs are expressed in primary transgenic shoots. This conclusion is in a way contradictory to the results obtained with the cytosine methylation inhibitor 5-azacytidine. For instance, the higher frequency of transformation in the presence of 5 -azacytidine was attributed to the recovery of clones that would otherwise be silenced by methylation (Mandal et al. 1993).

We found that many selected shoots had lost the T-DNA they were selected on: in A. thaliana, 27/115 and 32/223 shoots no longer contained the kanamycin-resistant and hygromycin-resistant T-DNAs, respectively, whereas 2/206 N. tabacum transformants did not contain the selected T-DNA anymore. These phenotypically sensitive transformants were analyzed and in most cases they had lost the selected T-DNA: therefore, these shoots do not contain a silenced T-DNA. At first sight, the most plausible explanation was to assume that the selected regenerated shoots were mosaic, as it is difficult to expose all cells of an explant to an antibiotic in a tissue explant cocultivation. Outgrowth of nontransformed tissues from the mosaic tissue after transfer to nonselective medium would thus account for the escape shoots from selection. However, these shoots were found to be transformed with the nonselected T-DNA with a frequency that was significantly higher (3/18 and 4/23; see Table 1) than expected on the basis of the obtained transformation frequencies (0/172). This suggests that the so-called escapes were at least transiently transformed with the selected T-DNA and that most sensitive shoots are the result of instability of the selected T-DNA. Presumably, the T-DNA can be lost during growth, differentiation, and regeneration when the selection pressure is released. How and when these cotransformants lose one or both their inserts is not yet determined. Also, it is not clear whether the expressed T-DNAs are lost before or after integration. Many A. thaliana mutations, however, obtained from a collection with T-DNA inserts were not linked to the T-DNA (Márton et al. 1994), suggesting that integration and subsequent excision of unstable T-DNAs may result in plant genomic mutations. Recently, a report convincingly showed that T-DNAs, which were stable during plant development as well as in transmission to the offspring, may become unstable during propagation in callus tissue (Risseeuw et al. 1997). The deletions occurred at variable frequencies depending on the chromosomal position of the target locus. We cannot explain the low percentage of tran- 
sient transformants after $N$. tabacum protoplast cocultivation compared with that after A. thaliana root cocultivation. The tobacco genome in protoplasts might be more tolerant for DNA integration and repair than the A. thaliana genome in differentiated root cells.

The cotransformation frequencies with a second detectable T-DNA were between 21 and $47 \%$ for A. thaliana root explants. The cotransformation frequencies of tobacco protoplasts with a second distinguishable T-DNA were also between 41 and $44 \%$ and approximately fourfold higher than the two single transformation frequencies (between 11 and 12\%). It can be assumed that the cotransformation frequency of the T-DNA identical to the selected T-DNA should equal the cotransformation frequency of the nonselected T-DNA. So, after the selection of a first T-DNA, $40 \%$ of the transformed cells are cotransformed with an identical T-DNA and $40 \%$ with a different T-DNA. The extrapolation of the results suggests that more than $64 \%(40 \%+40 \%$ of $60 \%)$ of the plants are cotransformed with two or more T-DNAs. These different T-DNAs subsequently tend to ligate or recombine before or after integration in approximately $70 \%$ of the analyzed cases (De Neve et al. 1997). This observation is in agreement with the fact that many Agrobacterium-transformed plants contain only one locus with an inverted repeat of two T-DNAs about the right border (Jorgensen et al. 1987, 1996; De Block and Debrouwer 1991; Grevelding et al. 1993; Hobbs et al. 1993; De Neve et al. 1997).

Remarkably, the cotransformation frequencies of two distinguishable T-DNAs are very similar in different systems. Our results are analogous with those found by Depicker et al. (1985), Petit et al. (1986), De Block and Debrouwer (1991), and Komari et al. (1996), and show that cotransformation of plant cells by different Agrobacterium strains occurs very frequently. As the cotransformation frequency is higher than the transformation frequency, we can conclude that cells that can stabilize one T-DNA have a higher chance to stabilize a second incoming T-DNA than cells that do not. This conclusion may be based on a particular competence and capacity of the cell to integrate nuclear transiently expressed DNA fragments. It is also possible that the increased efficiency of stabilization of a second T-DNA is the result of properties of the T-DNA transfer mechanism. Transfer of the T-strand-protein complex to the nucleus may be a highly organized and localized process that results in the cotransfer of independently transferred T-DNA copies. Ligation and cointegration of different T-DNAs are compatible with this latter idea (De Neve et al. 1997).

Copy number determination and genetic and molecular analysis of the different T-DNAs were performed for six different cotransformants (Table 1, RE1; Table 4 in De Neve et al. 1997). Only one of the six cotransformants contained one copy of each T-DNA. In the other five lines, multiple copies of one or both T-DNAs were inserted. Genetic and molecular characterization of other series of double transformants (data not shown) shows that in most selected lines more T-DNA copies were inserted than expected by the number of independent transformants events, suggesting that, besides multiple transformation events of individual cells, the transfer of multiple copies from the bacteria to the plant cell could also occur, or alternatively a limited amount of T-DNA replication in the plant cell.
In both systems, however, the cotransformation frequency is limited by a yet undefined parameter. As it is clear that the system is not saturated and given that there are approximately 70 bacteria per cocultivated plant cell, a theoretically much higher cotransformation frequency would be expected. One of the explanations may be that a major part of the bacteria is not competent to engage in a productive plant transformation interaction. It may also be that competent plant cells exhibit some kind of immunity immediately after the first successful T-strand infections (J. Bedbrook, personal communication). The compatibility followed by immunity would result in a very short time window during which plant cells could be transformed by the available and competent bacteria. Cocultivation with different amounts of bacteria that have been treated and preinduced in different ways should be informative on the influence of the bacterial inoculum on the transformation and cotransformation frequencies. Successive cocultivations with differently marked bacteria should allow us to define a postinfection immunity window and also whether this immunity would be based at the level of DNA transfer or at the level of T-DNA integration. Even when the basis of the cotransformation limitations is not identified, the biological meaning is clear: the seemingly low efficiency of transformation per bacterium has the advantage that the competent plant cells do not become loaded with hundreds of T-DNA copies. Integration of many T-DNA copies at different loci would be highly mutagenic and, moreover, would result in loci that would be highly susceptible for gene silencing.

\section{MATERIALS AND METHODS}

\section{Constructs and strains.}

The four different T-DNAs that were used for the cotransformation experiments are schematically represented in Figure 1 and can be subdivided into two types. A first T-DNA type, called the K T-DNA, carried the neomycin phosphotransferase II (nptII) gene conferring kanamycin resistance to transformed plant cells, whereas the second T-DNA type, called the $\mathrm{H}$ T-DNA, contained the hygromycin phosphotransferase (hpt) gene and provided hygromycin resistance. In a first series of experiments, the T-DNAs in plasmids pAK1202 and pAG1201 described by De Neve et al. (1993) were used as $\mathrm{K}_{1}$ and $\mathrm{H}_{1}$ T-DNAs, respectively. The T-DNA in plasmid pAK1202 was carried by the binary vector pVS1 (Deblaere et al. 1987), whereas the T-DNA in plasmid pAG1201 was maintained in A. tumefaciens by cointegration in the virulence plasmid pGV2260 (Deblaere et al. 1985). In a second series of experiments, two other T-DNAs were used. The $\mathrm{K}_{2} \mathrm{~T}$-DNA in plasmid pK2L610 contained a kanamycin resistance gene under control of the nopaline synthase (nos) promoter and a gus expression cassette under control of the cauliflower mosaic virus (CaMV) 35S promoter (P35S; Odell et al. 1985). The T-DNA vector pK2L610 was derived from the pXD610 plasmid (De Loose et al. 1995) by flanking the chimeric gus gene with lox sequences from pED32A (equivalent to pED32; Dale and Ow 1991) (pK1L610). An EcoRI fragment containing the lox site from pED32A was inserted into the EcoRI site of pK1L610. The $\mathrm{H}_{2}$ T-DNA in plasmid pH610 was equally derived from pXD610. The Pnos-nptII-3'nos cassette of pXD610 was exchanged for a Pnos-hpt-3'nos cassette of pGVmn (De Neve et al. 1993). This was done by insertion and ligation of three fragments, an 
EcoRI/KpnI fragment and an EcoRI/NheI fragment from pXD610, and a NheI/KpnI fragment from pGVmn (De Neve et al. 1993). pH610 contained a Pnos-hpt-3'nos cassette and a gus expression cassette under control of the CaMV 35S promoter. Both $\mathrm{K}_{2}$ and $\mathrm{H}_{2}$ T-DNAs of pK2L610 and pH610 were carried by the pVS1 binary vector.

The plasmids pAG1201, pAK1202, pK2L610, and pH610 were mobilized from Escherichia coli to A. tumefaciens C58C1Rif ${ }^{\mathrm{T}}(\mathrm{pGV} 2260)$ as described by Depicker et al. (1985). C58C1Rif ${ }^{\mathrm{T}}(\mathrm{pGV} 2260)$ had the chromosomal background of the wild-type A. tumefaciens C58 with a chromosomal rifampicin resistance mutation (Holsters et al. 1980) and the octopine-type vir plasmid pGV2260 (Deblaere et al. 1987).

\section{Transformation of A. thaliana.}

Transformation of root explants (RE) was done as described by Clarke et al. (1992) in a first cocultivation experiment (RE1). Because no $\mathrm{Hyg}^{\mathrm{r}}$ shoots could be regenerated with this protocol, the three subsequent cocultivation experiments (RE2, RE3, and RE4) were performed as described by Valvekens et al. (1988). There is only a minor difference between the two protocols after infection with the Agrobacterium strain. All the experiments were done with $A$. thaliana (L.) Heynh. 'C24'. Both transformation protocols gave green calli and shoots approximately 6 to 8 weeks after cocultivation. These shoots were put on selective $(50 \mathrm{mg}$ of kanamycin per liter or $20 \mathrm{mg}$ of hygromycin per liter) or nonselective germination medium (Valvekens et al. 1988) supplemented with cefotaxime $(100 \mathrm{mg} / \mathrm{liter})$. Single shoots from individual calli were placed in separate Falcon (Becton Dickinson, Bedford, MA) tubes to ensure the scoring of independent transformation events.

\section{Transformation of $\mathrm{N}$. tabacum protoplasts.}

For the preparation of protoplasts, sterile-grown plants of Nicotiana tabacum (L.) 'SR1' were used 8 weeks after propagation. After removal of the midrib in washing solution (B5 medium [Gamborg et al. 1968)] $+0.4 \mathrm{M}$ sucrose), the leaf halves were transferred to fresh washing solution and cut into pieces of 0.25 to $1 \mathrm{~cm}^{2}$. After $60 \mathrm{~min}$ of plasmolysis, the washing solution was removed and the leaf pieces were incubated overnight in $20 \mathrm{ml}$ of enzyme solution (B5 + 0.4 M sucrose $+0.5 \%$ cellulase R10 and $0.2 \%$ macerozyme R10). The

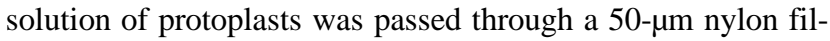
ter with a 10-ml plastic pipette. Both the petri dish and filter were subsequently washed with another $10 \mathrm{ml}$ of washing solution. After centrifugation of the protoplast solution $(4 \times 10$ $\mathrm{ml}$ ) for $10 \mathrm{~min}$ at $80 \times \mathrm{g}$ or $600 \mathrm{rpm}$ (Sorvall TC6; Dupont, Wilmington, DE) in a swinging bucket rotor, the enzyme solution was removed via a glass capillary by inserting it to the bottom and using a peristaltic pump until approximately 0.5 $\mathrm{ml}$ of solution with the floating protoplasts remained in the tube. The concentrated protoplasts were gently resuspended into $10 \mathrm{ml}$ of $\mathrm{K} 3$ medium supplemented with $0.4 \mathrm{M}$ sucrose, $0.2 \mathrm{mg}$ of benzylaminopurine (BAP) per liter and $1 \mathrm{mg}$ of naphthalene acetic acid (NAA) per liter, and the centrifugation was repeated. The protoplasts were counted in a hemacytometer and diluted to a final concentration of 1 to $2 \times 10^{5}$ protoplasts per $\mathrm{ml}$ in $\mathrm{K} 3$ medium with $0.4 \mathrm{M}$ sucrose, $0.2 \mathrm{mg}$ of BAP per liter, and $1 \mathrm{mg}$ of NAA per liter. The protoplasts were divided per $10 \mathrm{ml}$ into $9-\mathrm{cm}$ petri dishes and incubated at low light intensity. After 3 days, almost all the cells had a cell wall, which characteristically conferred an elongated shape to the cells. At that moment, $50 \mu \mathrm{l}$ was added of a late logarithmic phase $A$. tumefaciens culture, grown in nonselective minimal medium. Three days after cocultivation, cefotaxime was added to a final concentration of $500 \mathrm{mg} / \mathrm{liter}$. After a 2-day incubation, the cocultivated plant cells were diluted twofold with $5 \mathrm{ml}$ of $\mathrm{K} 3$ medium containing $0.4 \mathrm{M}$ sucrose, $0.2 \mathrm{mg}$ of BAP per liter, $1 \mathrm{mg}$ of NAA per liter, and $250 \mathrm{mg}$ of cefotaxime per liter. One week after cocultivation, the plant cells were divided into $5-\mathrm{cm}$ petri dishes and diluted to a final concentration of $4 \times 10^{4}$ protoplasts per ml with $\mathrm{K} 3$ medium supplemented with $1.4 \%$ agarose solution, $0.4 \mathrm{M}$ sucrose + $0.2 \mathrm{mg}$ of BAP per liter $+250 \mathrm{mg}$ of cefotaxime per liter. After solidification, the disks were placed in 9-cm petri dishes and embedded in liquid K3 medium. The liquid medium was refreshed every week. In the second and third week, K3 medium supplemented with $0.1 \mathrm{ml}$ of NAA per liter, $0.2 \mathrm{ml}$ of BAP per liter, $0.3 \mathrm{M}$ sucrose, $250 \mathrm{mg}$ of cefotaxime per liter, and $50 \mathrm{mg}$ of kanamycin per liter or $25 \mathrm{mg}$ of hygromycin per liter was used, whereas in the fourth and the fifth week K3 medium with $0.1 \mathrm{mg}$ of NAA per liter, $0.2 \mathrm{mg}$ of BAP per liter, $0.2 \mathrm{M}$ sucrose, and $250 \mathrm{mg}$ of cefotaxime per liter was used. After another 2 weeks, the growing calli were picked and placed on B5 medium supplemented with $0.1 \mathrm{mg}$ of NAA per liter, $1 \mathrm{mg}$ of BAP per liter, and $250 \mathrm{mg}$ of cefotaxime per liter. Shoots and calli were put on A5 medium (1/2 Murashige and Skoog salts, $3 \%$ sucrose, $0.5 \mathrm{~g}$ of 2-[N-morpholino] ethanesulfonic acid [MES] per liter [pH 5.7], and $100 \mathrm{mg}$ of cefotaxime per liter) and allowed to regenerate in small plantlets.

\section{Callus induction test on leaf tissue and root material.}

Screening for the presence of either a $\mathrm{K}$ and/or $\mathrm{H}$ T-DNA in plants regenerated from an A. tumefaciens cocultivation experiment was done by a callus induction test. For A. thaliana, leaves were taken from 3- to 4-week-old $S_{1}$ seedlings grown on nonselective medium and put on medium with kanamycin or hygromycin (C1 medium) (Van Lijsebettens et al. 1991). Alternatively, roots of primary regenerated A. thaliana shoots were cut and incubated on $0.5 / 0.05$ callus induction medium (CIM) (B5 salts, $2 \%$ glucose, $0.5 \mathrm{~g}$ of MES per liter [pH 5.7], $0.8 \%$ agar, $0.5 \mathrm{mg}$ of 2,4-dichlorophenoxyacetic acid [2,4-D] per liter, and $0.05 \mathrm{mg}$ of kinetin per liter). After 4 days, the roots were transferred to $0.15 / 5.0$ shoot-inducing medium (SIM) (B5 salts, $2 \%$ glucose, $0.5 \mathrm{~g}$ of MES per liter [pH 5.7], $0.8 \%$ agar, $5 \mathrm{mg}$ of $6[\gamma, \gamma$-dimethylallylamino]purine [2ip] per liter, and $0.15 \mathrm{mg}$ of indole-3-acetic acid [IAA] per liter), supplemented either with $50 \mathrm{mg}$ of kanamycin per liter or with 20 $\mathrm{mg}$ of hygromycin per liter. After 2 to 3 weeks, resistant roots turned green and started to form shoots, whereas sensitive roots turned yellow and died.

For N. tabacum, the callus induction test was done on leaf material of primary transformants. Leaves were placed on medium (B5 medium with $30 \mathrm{~g}$ of sucrose per liter [pH 5.6], $0.1 \mathrm{mg}$ of NAA per liter, and $1 \mathrm{mg}$ of BAP per liter) supplemented with $50 \mathrm{mg}$ of kanamycin per liter or $25 \mathrm{mg}$ of hygromycin per liter.

\section{Plant DNA preparation.}

DNA was isolated from leaf material of $N$. tabacum as described by Jones et al. (1985). After lithium precipitation of 
the RNA, the DNA in the supernatant was pelleted by an ethanol or isopropanol precipitation and resuspended. DNA of A. thaliana leaf material was prepared as described by De Neve et al. (1997).

\section{Molecular analysis.}

Making the probes, hybridization, and detection of the hybridized probes were performed according to the manufacturers' instructions (ICN Biomedicals, Costa Mesa, CA, and Amersham, Aylesbury, UK). Two different nonradioactive detection kits were used: the Aurora Southern blot kit (ICN) and the "Gene images" random prime labeling module and the "Gene images" CDP-Star detection module (Amersham). The presence of both T-DNAs was assessed on the basis of two Southern hybridizations with T-DNA-specific probes.

\section{ACKNOWLEDGMENTS}

We thank Andrée Dedonder, Myriam De Neve, Godelieve Gheysen, Koen Goethals, and Mieke Van Lijsebettens for critical reading of the manuscript and helpful comments, Benny Carlier and Isabelle Strobbe for technical assistance, Martine De Cock for lay-out, Rebecca Verbanck for preparation of the figures, and Karel Spruyt for photographic work. This work was supported by grants from the Belgian Programme on Interuniversity Poles of Attraction (Prime Minister's Office, Science Policy Programming, No. 38) and the European Union Human Capital and Mobility Network (CHRX-CT94-0530). S. D. B. is indebted to the Vlaams Instituut voor de Bevordering van het Wetenschappelijk-Technologisch Onderzoek in de Industrie for a predoctoral fellowship.

\section{LITERATURE CITED}

Benediktsson, I., Spampinato, C. P., and Schieder, O. 1995. Studies of the mechanism of transgene integration into plant protoplasts: Improvement of the transformation rate. Euphytica 85:53-61.

Binns, A. N. 1991. Transformation of wall deficient cultured tobacco protoplasts by Agrobacterium tumefaciens. Plant Physiol. 96:498-506.

Binns, A. N., and Thomashow, M. F. 1988. Cell biology of Agrobacterium infection and transformation of plants. Annu. Rev. Microbiol. 42:575-606.

Bower, R., and Birch, R. G. 1990. Competence for gene transfer by electroporation in a sub-population of protoplasts from uniform carrot cell suspension cultures. Plant Cell Rep. 9:386-389.

Clarke, M. C., Wei, W., and Lindsey, K. 1992. High-frequency transformation of Arabidopsis thaliana by Agrobacterium tumefaciens. Plant Mol. Biol. Rep. 10:178-189.

Dale, E. C., and Ow, D. W. 1991. Gene transfer with subsequent removal of the selection gene from the host genome. Proc. Natl. Acad. Sci. USA 88:10558-10562.

De Block, M., and Debrouwer, D. 1991. Two T-DNA's co-transformed into Brassica napus by a double Agrobacterium tumefaciens infection are mainly integrated at the same locus. Theor. Appl. Genet. 82:257-263.

De Loose, M., Danthinne, X., Van Bockstaele, E., Van Montagu, M., and Depicker, A. 1995. Different $5^{\prime}$ leader sequences modulate $\beta$ glucuronidase accumulation levels in transgenic Nicotiana tabacum plants. Euphytica 85:209-216.

De Neve, M., De Buck, S., Jacobs, A., Van Montagu, M., and Depicker, A. 1997. T-DNA integration patterns in co-transformed plant cells suggest that T-DNA repeats originate from co-integration of separate T-DNAs. Plant J. 11:15-29.

De Neve, M., De Loose, M., Jacobs, A., Van Houdt, H., Kaluza, B., Weidle, U., Van Montagu, M., and Depicker, A. 1993. Assembly of an antibody and its derived antibody fragment in Nicotiana and Arabidopsis. Transgenic Res. 2:227-237.

Deblaere, R., Bytebier, B., De Greve, H., Deboeck, F., Schell, J., Van Montagu, M., and Leemans, J. 1985. Efficient octopine Ti plasmidderived vectors for Agrobacterium-mediated gene transfer to plants.
Nucleic Acids Res. 13:4777-4788.

Deblaere, R., Reynaerts, A., Höfte, H., Hernalsteens, J.-P., Leemans, J., and Van Montagu, M. 1987. Vectors for cloning in plant cells. Pages 277-292 in: Recombinant DNA, part D (Methods in Enzymology, Vol. 153). R. Wu and L. Grossman, eds. Academic Press, New York.

Depicker, A., Herman, L., Jacobs, A., Schell, J., and Van Montagu, M. 1985. Frequencies of simultaneous transformation with different TDNAs and their relevance to the Agrobacterium/plant cell interaction. Mol. Gen. Genet. 201:477-484.

Depicker, A., and Van Montagu, M. 1997. Post-transcriptional gene silencing in plants. Curr. Opin. Cell Biol. 9:373-382.

Dillen, W., De Clercq, J., Van Montagu, M., and Angenon, G. 1996. Plant regeneration from callus in a range of Phaseolus acutifolius A. Gray genotypes. Plant Sci. 118:81-88.

Escudero, J., Neuhaus, G., Schläppi, M., and Hohn, B. 1996. T-DNA transfer in meristematic cells of maize provided with intracellular Agrobacterium. Plant J. 10:355-360.

Gamborg, O. L., Miller, R. A., and Ojima, K. 1968. Nutrient requirements of suspension cultures of soybean root cells. Exp. Cell Res. 50:151-158.

Geier, T., and Sangwan, R. S. 1996. Histology and chimeral segregation reveal cell-specific differences in the competence for shoot regeneration and Agrobacterium-mediated transformation in Kohleria internode explants. Plant Cell Rep. 15:386-390.

Grevelding, C., Fantes, V., Kemper, E., Schell, J., and Masterson, R. 1993. Single-copy T-DNA insertions in Arabidopsis are the predominant form of integration in root-derived transgenics, whereas multiple insertions are found in leaf discs. Plant Mol. Biol. 23:847-860.

Hobbs, S. L. A., Warkentin, T. D., and DeLong, C. M. O. 1993. Transgene copy number can be positively or negatively associated with transgene expression. Plant Mol. Biol. 21:17-26.

Holsters, M., Silva, B., Van Vliet, F., Genetello, C., De Block, M., Dhaese, P., Depicker, A., Inzé, D., Engler, G., Villarroel, R., Van Montagu, M., and Schell, J. 1980. The functional organization of the nopaline A. tumefaciens plasmid pTiC58. Plasmid 3:212-230.

Janssen, B.-J., and Gardner, R. C. 1989. Localized transient expression of GUS in leaf discs following cocultivation with Agrobacterium. Plant Mol. Biol. 14:61-72.

Jones, J. D. G., Dunsmuir, P., and Bedbrook, J. 1985. High level expression of introduced chimaeric genes in regenerated transformed plants. EMBO J. 4:2411-2418.

Jorgensen, R., Snyder, C., and Jones, J. D. G. 1987. T-DNA is organized predominantly in inverted repeat structures in plants transformed with Agrobacterium tumefaciens C58 derivatives. Mol. Gen. Genet. 207: 471-477.

Jorgensen, R. A., Cluster, P. D., English, J., Que, Q., and Napoli, C. A. 1996. Chalcone synthase cosuppression phenotypes in petunia flowers: comparison of sense vs. antisense constructs and single-copy vs. complex T-DNA sequences. Plant Mol. Biol. 31:957-973.

Kapila, J., De Rycke, R., Van Montagu, M., and Angenon, G. 1997. An Agrobacterium-mediated transient gene expression system for intact leaves. Plant Sci. 122:101-108.

Komari, T., Hiei, Y., Saito, Y., Murai, N., and Kumashiro, T. 1996. Vectors carrying two separate T-DNAs for co-transformation of higher plants mediated by Agrobacterium tumefaciens and segregation of transformants free from selection markers. Plant J. 10:165-174.

Mandal, A., Lång, V., Orczyk, W., and Palva, E. T. 1993. Improved efficiency for T-DNA-mediated transformation and plasmid rescue in Arabidopsis thaliana. Theor. Appl. Genet. 86:621-628.

Márton, L., Hrouda, M., Pécsváradi, A., and Czakó, M. 1994. T-DNAinsert-independent mutations induced in transformed plant cells during Agrobacterium co-cultivation. Transgenic Res. 3:317-325.

Matzke, M. A., and Matzke, A. J. M. 1995. How and why do plants inactivate homologous (trans)genes? Plant Physiol. 107:679-685.

Meyer, P., and Saedler, H. 1996. Homology-dependent gene silencing in plants. Annu. Rev. Plant Physiol. Plant Mol. Biol. 47:23-48.

Meyer, P., Walgenbach, E., Bussmann, K., Hombrecher, G., and Saedler, H. 1985. Synchronized tobacco protoplasts are efficiently transformed by DNA. Mol. Gen. Genet. 201:513-518.

Nam, J., Matthysse, A. G., and Gelvin, S. B. 1997. Differences in susceptibility of Arabidopsis ecotypes to crown gall disease may result from a deficiency in T-DNA integration. Plant Cell 9:317-333.

Narasimhulu, S. B., Deng, X.-b., Sarria, R., and Gelvin, S. B. 1996. Early transcription of Agrobacterium T-DNA genes in tobacco and 
maize. Plant Cell 8:873-886.

Odell, J. T., Nagy, F., and Chua, N.-H. 1985. Identification of DNA sequences required for activity of the cauliflower mosaic virus $35 \mathrm{~S}$ promoter. Nature (London) 313:810-812.

Peach, C., and Velten, J. 1991. Transgene expression variability (position effect) of CAT and GUS reporter genes driven by linked divergent T-DNA promoters. Plant Mol. Biol. 17:49-60.

Petit, A., Berkaloff, A., and Tempé, J. 1986. Multiple transformation of plant cells by Agrobacterium may be responsible for the complex organization of T-DNA in crown gall and hairy root. Mol. Gen. Genet. 202:388-393.

Risseeuw, E., Franke-van Dijk, M. E. I., and Hooykaas, P. J. J. 1997. Gene targeting and instability of Agrobacterium T-DNA loci in the plant genome. Plant J. 11:717-728.

Sahi, S. V., Chilton, M.-D., and Chilton, W. S. 1990. Corn metabolites affect growth and virulence of Agrobacterium tumefaciens. Proc. Natl. Acad. Sci. USA 87:3879-3883.

Sangwan, R. S., Bourgeois, Y., Brown, S., Vasseur, G., and SangwanNorreel, B. 1992. Characterization of competent cells and early events of Agrobacterium-mediated genetic transformation in Arabidopsis thaliana. Planta 188:439-456.
Schläppi, M., and Hohn, B. 1992. Competence of immature maize embryos for Agrobacterium-mediated gene transfer. Plant Cell 4:7-16.

Sheng, J., and Citovsky, V. 1996. Agrobacterium-plant cell DNA transport: Have virulence proteins, will travel. Plant Cell 8:1699-1710.

Sonti, R. V., Chiurazzi, M., Wong, D., Davies, C. S., Harlow, G. R., Mount, D. W., and Signer, E. R. 1995. Arabidopsis mutants deficient in T-DNA integration. Proc. Natl. Acad. Sci. USA 92:11786-11790.

Stam, M., Mol, J. N. M., and Kooter, J. M. 1997. The silence of genes in transgenic plants. Ann. Bot. 79:3-12.

Tinland, B. 1996. The integration of T-DNA into plant genomes. Trends Plant Sci. 1:178-184

Valvekens, D., Van Montagu, M., and Van Lijsebettens, M. 1988. Agrobacterium tumefaciens-mediated transformation of Arabidopsis thaliana root explants by using kanamycin selection. Proc. Natl. Acad. Sci. USA 85:5536-5540.

Van Lijsebettens, M., Vanderhaeghen, R., and Van Montagu, M. 1991. Insertional mutagenesis in Arabidopsis thaliana: Isolation of a TDNA-linked mutation that alters leaf morphology. Theor. Appl. Genet. 81:277-284.

Zupan, J. R., and Zambryski, P. 1995. Transfer of T-DNA from Agrobacterium to the plant cell. Plant Physiol. 107:1041-1047. 